2. "On a New Cave on the Eastern Side of Gibraltar." By Henry Dyke Acland, Esq., F.G.S.

This cave, discovered in 1902 , is situated a short distance south of the eastern end of the tunnel, which pierces the Rock from the Dockyard on the western side to 'Monkey»' Quarry' on the eastern. It was opened by blasting operations; and from the opening thus made, 88 feet above sea-level, the floor falls to the west. The main hall is about 70 feet high and 45 feet wide, and has a smooth stalagmite floor resting on breccia and a stalactitic roof covering the limestone of the Rock. Its floor falls to a point 19 feet above sea-level. The lower gallery descends at its far end to little, if anything, short of sea-level. Its floor consists of stalagmite resting on fine calcareous sand; this on coarse sand, followed by rubbly and calcareous grit, which in time rests on the rock-floor of the cave at a depth of 15 feet. In the calcareous grit are numerous well-rounded stones, some pierced by pholades. At a depth of 13 feet were echinids and barnacles. Two other galleries were explored, and in these, as in the lower gallery, the walls are pitted to a height of 28 feet above sea-level. 'The author concludes that the cave existed at first as a fissure, to which the sea later obtained access through a large entrance for a long period; and during this period the Rock was elevated some 42 feet. The cave was closed to the sea at a period geologically recent; and the breccia and sand-slopes at this point on the eastern side of the Rock, which are 150 feet wide and reach to a height of 200-300 feet above sea-level, date from a still more recent period.

\title{
COREESPONDENOE.
}

\section{A FINAL WORD ON FLUID INCLUSIONS.}

Sir,-I am very sincerely obliged to General McMahon for his full reply to my paper on granite. I can assure him that he is mistaken in supposing my motives to be sinister.

Since the late W. Pengelly, F.R.S., in 1862, read his paper "On the Age of the Dartmoor Granites" (mark the plural), the granite problem bas greatly interested local geologists, who, for forty-one years, have fought over the question with equal keenness and good temper.

General McMahon now writes, "My critic's conclusion is irreconcilable with the facts stated in my Belfast address, hence possibly his anxiety to discredit my facts under cover of an attack on the views expressed by me"! Now I never to my knowledge bolstered a theory, or sought to discredit a fact; and, so far from wishing to discredit General McMahon's facts, I should be as pleased to see his theory confirmed as anyone else's, and certainly as well as my own. With regard to my being called upon to defend my position by proving Dr. Sorby's views erroneous, I think Genera McMahon must have had in his mind Dr. Sorby's paper of 1858. My authority as to the significance of deposited chlorides is chiefly 
his paper of 1876 . Dr. Sorby, no doubt, showed tbat certain fluids are caught up during the consolidation of crystals, and I have confirmerl that observation over and over again; but that established fact does not preclude the possibility of the same crystal being subsequently cracked, and a new, and perhaps an entirely different, set of fluids being introduced; and that possibly more than once.

General McMahon, in his reply, furnishes an example of the very statements which have so perplexed me; e.g., "The potential energy of water held in a fluid state by pressure must have been great." This was at above red heat. A few lines later we read, "I thought experts would understand that I had water in a gaseous state in my mind" (italics mine).

If, as General McMahon points out, Dr. Sorby proved certain inclusions to contain water, or rather salts dissolved in water, his more triumphant diagnosis was liquid carbonic acid; as he has himself observed-." people would scarcely believe that there were such things as fluid cavities in granite, and no one had imagined such a thing as liquid carbonic acid." If anyone convicts me of dissenting from Dr. Sorby's opinion on any subject on which he has all the known facts before him, I will say with the opossum, "Don't shoot, Colonel, I will come down."

I really am very sorry that my recent papers should have vexed either Professor Bonney or General McMahon. The untoward result was quite unforeseen, and shall not occur again.

Torquax, November 5, 1903.

A. R. Hunt.

\section{OBITUARY. \\ THE REV. MAXWELL HENRY CLOSE, M.A., \\ MTEIB. R. I. $\triangle C A D .$, R.D.S., R.G.S.I., F.G.S. \\ BokN 1822. \\ Died SEPtember, 1903.}

WE regret to announce the death of the Rev. Maxwell Henry Close, Treasurer of the Royal Irish Academy, at his residence, 38, Lower Baggot Street, Dublin. Mr. Close, who bad attained the venerable age of 81 years, was, up till a very short time since, daily to be seen at the Academy's house in Dawson Street. With the passing of Mr. Close a familiar figure in Dublin life has disappeared, greatly to the regret of a large circle, who knew and esteemed him for his scholarly attainments and genial personality. The son of the late Mr. Henry S. Close, Newtown Park, county Dublin, Mr. Maxwell Close was born in 1822. At a comparatively early age he entered Dublin University, where he graduated in 1846. He received the Divinity Testimonium, and in 1847 the degree of Master of Arts. In 1847 be took holy orders, becoming a priest the following year, and went to reside in England as curate of All Saints, Northampton, until 1849, when he was inducted Rector of Shangton, Leicestershire. He resigned this position eight years later, and 